\title{
HOLISTIC MUSIC THERAPY AS ONE OF THE PREVENTIVE ACTIVITIES IN PUPILS WITH PROBLEM BEHAVIOR
}

\author{
Irena Johanka Savková
}

\begin{abstract}
The paper provides insight into the implementation of music therapy activities within holistic music therapy. In its first part, it conveys theoretical information about holistic music therapy, which can be very flexibly applicable. In the second part, the author focuses on the application of music therapy in a special primary school environment with a target group of students with a combined disability and severe mental disability. It presents the forms, the course of lessons, the specifics of music therapy activities and a specific case study of the student, in which he describes the course of music therapy lessons. The last part of the paper consists of a description of the project of holistic music therapy for pupils with manifestations of problematic and risky behavior in the primary school in Bohumín and its evaluation.
\end{abstract}

\section{Keywords}

comprehensive music therapy, educational drumming, special primary school, pupils with problem behavior, project

\section{Introduction}

Music therapy in the Czech Republic can be considered a relatively young field. J. A. Komensky was the first important person to attach great importance to music in the upbringing of children. In his work Informatorium for Kindergartens, he recommends leading children to learn about melody, rhythm through music that is natural for humans. Nowadays, music therapy can be studied at universities. Knowledge and personal experience can be gained by attending seminars, educational programs organized by Czech music therapy associations and non-profit organizations. In the Czech Republic, we record various approaches to music therapy. Their origin was influenced by traditions, culture, music therapy foreign directions and other factors. Music therapy has a therapeutic 
and therapeutic character, it is used in the field of health care, education, in the social sector and in non-profit organizations. It is impossible to say which approach is better or "the right one", the course and subsequent influence of music therapy is influenced by a number of factors, the choice of form of music therapy, instruments, personality and experience of a music therapist. However, all approaches have a common goal: to comprehensively affect the development of the personality of the student, client, patient.

The article brings, among other things, the experience with the use of Holistic Music Therapy according to L. Holzer in the Kindergarten and primary school special Diakonie ČCE Ostrava. The mission of this school is the education of children and pupils with combined disabilities. These are combinations of mental disabilities with various forms of cerebral palsy, sensory impairments, autism, autistic traits. Most children here are fully immobile, non-communicating, verbally requiring the help of another person throughout the teaching. Some students have a tracheostomy and pegs. It is typical of $\mathrm{L}$. Holzer's Holistic Music Therapy that natural tuning instruments are used, which have a positive effect on the human body. These are folk, ethnic, non-tempered instruments, rich in aliquots, eg drums, djembe, balafon, koshi bells, shanti chimes, rain stick, ocean drum, percussion instruments, frame drums, endings, fujars, twins, didgerida, gongs, Tibetan bowls, sansula, kalimba, squirrels, mouth harps, slit drums, udu, shruti box and more. An irreplaceable element here is the musical rhythmic instrument that we all have within us - the human voice. Aliquot singing, intuitive singing, voice tone color, accompaniment of playing instruments with a voice are used. No folk songs or lyrics are used, it is improvisation. He does not use reproduced music, guitar or piano. Pupils perceive the sounds of these instruments with all their senses. The vibrations they perceive during play through the largest sensory organ - through the skin, help them to realize their body as a whole, to feel their body "from within", affects the internal organs and muscle tone.

\section{Music therapy in special primary school}

An active and receptive form of music therapy, individual and group, is implemented in the facilities of the special primary school. The form, space and instruments are chosen by the music therapist so that the course of music therapy is suitable for specific pupils or pupils, they must know his current state of health, mental state, individual approach is necessary. During active music therapy, students are involved in playing instruments, the body, vocal expression, rhythmic movements of the body, limbs. In the receptive (listening) form, the children are suitably positioned and let the sounds of the instruments played by the music therapist play on them. Previously, this form of music therapy was mistakenly referred to as "passive" because children do not play instruments. However, children perceive the stimuli offered and respond to them adequately, involving them in the process, by voice expression, rhythms. 
The individual form of music therapy takes place in a separate multisensory room, in Snoezelen, which provides an undisturbed safe space, suitable lighting - dimming, is equipped with a sufficient number of positioning aids, musical instruments. Here, a music therapist devotes 30 to 60 minutes to one child. He chooses the time and choice of tools according to the individual needs of the child. The music therapist prepares the room - ventilation, preparation of instruments, positions the child so that the position is pleasant, safe for him, with the support of the head, or to the half-seat. Children try to watch where the sounds come from, sometimes they need to look at the music therapist. The increase in the upper part of the body allows them to do this, in addition it facilitates breathing and the possibility of vocal expression.

The group form of therapy takes place once a week according to the number of participating children and pedagogical staff either in multisensory rooms, in a spacious separate classroom, in a rehabilitation room, depending on the weather and in the school garden. It is essential that the space is large enough for all involved, does not restrict them in movement, playing, provide space for instruments, a quiet undisturbed and safe environment. Educators and children sit in a circle on chairs, in wheelchairs, on a positioning bag, in front of them they have a drum - djembe, tubano, drums with a mallet. The type of drum is chosen according to the child's motor skills. Some fully immobile students are positioned inside the circle. In the center of the circle is a menu area with percussion instruments. After the welcome, they play drums together under the guidance of a music therapist, create common rhythms, and vocalize. Children for whom drumming is impossible due to a disability play percussion instruments. A popular activity is not only joint drumming, but also the creation of a common rhythm, music within the so-called music therapy orchestra. Children and teachers will choose from the menu area the instrument they will want to play - shakers, percussion, wooden blocks, sounding sticks, bells, scrubs and use them to create a common musical composition. The duration of the active form of music therapy is 1-1.5 hours.

Unwritten principles apply in the facility, for music therapists, but also for pedagogical staff who participate in music therapy:

- Create a quiet, safe space to experience the effects of unreproduced music (considered the most effective here)

- To support and respect the individuality of the student

- Music therapy is performed by a qualified pedagogical worker who has completed the educational program, has theoretical knowledge and his own experience with the effects of holistic music therapy

- Know and follow the ethical principles of music therapy

- He is capable of self-reflection, self-education

- Monitor children's feedback, their verbal and nonverbal expressions

- The worker who is present at the receptive music therapy does not interfere in the course, the child does not stroke, does not speak

- In the active form of music therapy, we respect the manifestations of the child, we do not moderate them, we do not correct them, we do not shout

- Children are involved in imitation

- The process is managed by a music therapist, we all follow his instructions 
- All pedagogical staff have the right to comment on the evaluation of the course of music therapy, they know their pupils best, they are able to adequately and objectively evaluate the effects of the lesson.

The pedagogical staff of this school evaluates the regular implementation of music therapy very positively. They noted that music therapy in children:

- Reduces muscle tone in students

- There is total relaxation, inducing pleasant feelings

- Positively influences speech, speech rhythm, children vocalize, add vocally, hum

- Activation of the orofacial area

- Establishing visual contact, prolonging visual perception

- Supports auditory discrimination and spatial orientation

- Supports perception, remember and respect the sequence of individual actions

- Induction of calm, well-being, reduces states of restlessness, hyperactivity, disharmony

- Helps to establish a teacher $x$ student relationship

- Supports mutual communication between students, joint work in a group

- Supports the ability of imitation, mirroring

- Hand rotation promotes interaction between the right and left hemispheres

- Overall improvement of body coordination, fine motor skills, graphomotor skills.

Figure 1 Music therapy in a special primary school in Ostrava

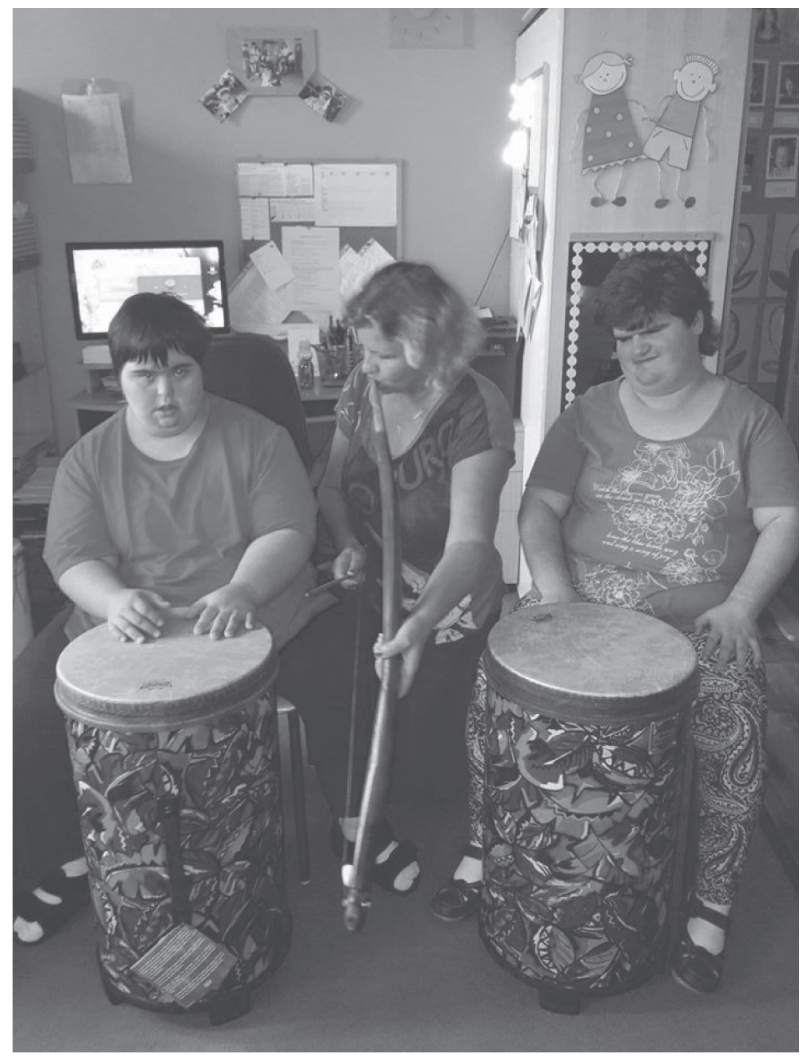




\section{As an inspiring approach to music therapy in a special primary school, we present the following case study:}

Boy 17 years, cerebral palsy the spastic form of quadriplegia, other mental retardation, compensated partial epilepsy, hydrocephalus. The boy has been a pupil of this school since he was 5 years and 8 months old, ie since September 2010, when he attended the preparatory stage of primary school. Since September 2012, he has been fulfilling compulsory school attendance. The boy is educated according to the school educational program for special primary school.

Personal anamnesis

The mother was not ill during pregnancy but was on a high-risk pregnancy due to a previous premature birth. All tests during pregnancy were fine, no findings. The boy was born at 24 week, birth weight was $700 \mathrm{~g}$ and measured $29 \mathrm{~cm}$. Childbirth after the spontaneous outflow of amniotic fluid was complicated. After birth, the boy was raised and there was a total contusion of the child. After birth, there was severe bleeding into the brain and subsequent development of post hemorrhagic hydrocephalus, repeatedly resolved by punctures. Due to the immaturity of the lungs, it was incubated immediately after birth, placed in an incubator and taken to the ICU. Brain drainage introduced in three months, repeated revisions, frequent infections. He was probed for a long time. He began rehabilitating at the age of eleven months with Vojta's reflex locomotion method, after which, unfortunately, appeared epileptic paroxysms.

In a boy was diagnosed a severe multiple disability that involves CNS dysfunctions. Cerebral palsy with a more pronounced expression on the right upper limb and left lower limb, manifested by increased muscle tension (hypertension) and impaired coordination of motor processes. Increased tension affects the whole body, especially controlled motor skills, which leads to increased irritability and spasticity. Stereotypical movement patterns predominate. When trying some motor activity, spasms of the upper and lower limbs occur at the same time and thus grip is significantly reduced, the spasms of the limbs also increase by eating and feeding. Due to a significant motor disability, his mental abilities are difficult to assess. His sensory perception, communication skills and overall psychosocial development are greatly limited. This results in a global psychomotor developmental delay approximately corresponding to severe mental disabilities.

Music therapy with this boy takes place at least once a week. On Friday there is an active form of music therapy, during the other days individually receptive form of music therapy in Snoezelen. As part of the group music therapy, the boy is placed on a bag - he is part of a circle of children, percussion, bells, shakers are placed in his hands and he rhythmizes with the others. After inserting the mallet into his hand, he tries to rhythmically tap into the sound stones of the balaphon. Within the Snoezelen environment, he is positioned in a nest on a trampoline so that he has the opportunity to watch what is happening in the room and watch the music therapist play instruments - basket bells, mountain fujara, hum, djembe, Tibetan bowls, Indian flute etc.

The boy is looking forward to music therapy, he shows it with a smile and sounds he tries to sing, we see cheerful expressions on his face. He engages in spontaneous 
percussion, relaxes muscle tone, rhythmizes the lower limbs, tries to "dance" to move the whole body, torso during fast movements. Everything is accompanied by smiles, sounds, loud laughter and cheers. He notices when changing instruments, followed by a bigger breath and a longer exhalation. He loves the sound of humble, didgerid and shiotanka. He observes other children during collective music therapy. There is a total relaxation of the body, deepening and regularization of the breath, often immersed in sounds and enjoying rhythms with closed eyes. He responds very well to sounds. He turns behind them. He watches the instruments game closely, sometimes he gets involved independently. He accepts body play. The main goal of the therapy is relaxation, inducing pleasurable feelings, improving of the mood, strengthening concentration of attention. Overall, the boy is after music therapy lessons more receptive and attentive, the time of concentration of attention to the specified activity has increased and visual contact has prolonged.

\section{Project „Joint Drumming”}

Music, rhythm, drumming are among the oldest instruments of communication and joint drumming is the oldest form of teamwork. Rhythm is a universal language that can transcend differences between people - nationality, gender, age, race, health restrictions, communication difficulties, physical and sensory disabilities. It is a non-verbal, primary way of communication, which reveals the stereotypes experienced in the communication of the group. Each person represents one tone, even if that tone is perfect, he will never play the melody himself. Only a joint interplay with others - other tones - will create a beautiful melody, harmony, success.

The project "Joint Drumming", which took place in the primary school in Bohumín, focused on the specific primary prevention of problematic and risky manifestations of pupils' behavior. It was financed from a non-investment grant from the budget of the MoravianSilesian Region. The possibility of financing the program brought to the school music therapy, drumming, active playing a musical instrument for each student.

The primary school is located on the outskirts of the town Bohumín, whose pupils are mainly from socio-culturally disadvantaged and different backgrounds, especially the Roma pupils. One third of pupils are diagnosed by mild mental difficulties. These chlildren are easy target of the temptations of the environment: theft, verbal and physical aggression, wandering, abusing of alcohol and drugs, smoking etc.

The project focused primarily on children in the preparatory class and pupils in the 1st grade (approximately 60 pupils), as they are still open to our work during this period. At this age, it is still possible to influence and perhaps change the opinions and attitudes of children, which they bring from the families and are not allowed at schools. In order for this influence of the teacher and the teaching assistant to be more targeted and conscious, we need to get to know the pupils even more. We know them best in moments of controlled activity, which is close to them, in which they can fully manifest 
themselves. And at the same time, they themselves feel that they are actually playing. The close activity in this case is playing a musical instrument - drums, percussion and other like. The secondary target group was other pupils of the school (40 pupils), families of pupils and all school staff (20 persons).

\section{Description of project implementation according to activities}

- support for children and pupils of the school (eight hours meeting within the class in the period from September to December of the following year, ie 14 months). Number of children and pupils: 60, of which 1/4 were disabled (mild mental disabilities, hearing and speech dificulties);

- support for teachers - a total of 8 meetings: the first meeting took place before the start of activities with children and pupils, teachers were informed about the structure of lessons, about the activities of pupils and their demands on them. The other meetings took place after the lessons with the pupils, when the music therapist and the teachers present at the lesson with the children evaluated the course of the music therapy lesson, pupils' behavior and activities etc. A total of 8 pedagogical staff participated: 5 teachers, 3 teaching assistants;

- support for the material provision of the project and subsequent continuation by purchasing musical instruments in the total value of 52.000 CZK. The school bought djembe, cajon, percussion, shakers, wooden blocks, slotted drums, agoga, kabasy, rain stick, kalimba, etc.

\section{Project goals}

- knowledge of pupils - diagnostic goal

- releasing aggression and working with it

- activation of pupils - prolongation of concentration, concentration, interest in activities, support of creativity

- cooperation - playing together according to the rules of who controls the activity, mutual respect for the uniqueness of personalities, spontaneous group creation of a common rhythm

- development of communication skills.

\section{Implementation}

Active music therapy classes were held once a month, always on Mondays in one specific class, and pupils and teachers of a specific class attended here according to the schedule. The hour lasted 45 minutes, ie. that it was part of the morning class. 
- 1st lesson preparatory level + 1st grade pupils a total of 20 children

- 2nd lesson pupils of the second and fifth year a total of 21 children

- 3rd lesson third and fourth grade students a total of 19 children

- 4th lesson pupils of the fourth and fifth year a total of 11 pupils

- 5th lesson consultation with pedagogical staff.

The room, which is defined for active music therapy, is spacious, there are chairs of three sizes available to ensure a suitable sitting in a circle for all participating students and teachers. The middle of the circle is the offer of percussion instruments. Active music therapy is led by a music therapist.

\section{Structure of music lesson}

- Greeting - sending the basket from the outside, reminding the rules, space for relaxation, group tuning

- Active game on jam - warm-up, basic strokes, rhythm creation, joint rhythmization using simple children's songs

- Music therapy orchestra - spontaneous percussion, collective creation

- Receptive form - listening to samsula, hum, play shiotanka

- Termination - by sending the basket from the outside, the children pass on space for feedback on what he liked, what he did well, how he feels.

During the play, all activities are conducted so that the students relax, begin to realize their place in the environment and the class team, they are not alone in the classroom and learn to work together. Spontaneous play awakens their inner motivation, desire to discover and learn. It develops partnerships and confidence in oneself, in one's abilities and skills, responsibility for a common work. Each lesson when students meet is unique, original - created according to the immediate needs of pupils. Teachers working in the classes monitor the attendance of students, actively participate in all activities together with the others, observe how students manifest themselves in a lesson and in the time between meetings. They use their knowledge for early diagnosis. The results of this observations are lately discussed during interview with the lecturer - music therapist and teachers.

Evaluating the effectiveness of education is challenging, it is not very possible to quantify manifestations, because the experience is very personal. However, by observing in everyday practice, teachers are able to catch changes in the behavior of pupils.

Criteria:

- outputs from the observation of pedagogical staff working in individual classes fulfillment of the agreed goal

- calming pupils and improving the class climate, and subsequently school climate

- conclusions from observations of pedagogical staff. 
To meet our results, we needed the records of pedagogical staff in the participation and changes in pupils, feedback obtained after the end of each block, observation of pupils' behavior and actions during teaching.

The children were always looking forward to music therapy, they tried to get maximum of our attention, most of them had short-term attention and distraction. Playing drums was very motivating for them. Most of them had a problem with changing hands during the game (connecting the right and left hemispheres), they quickly got tired, it was necessary to monitor their nonverbal feedback, alternate activities and verbally motivate them. At the beginning, it was necessary to set up the rules, pay attention to their observance, the lesson ended with feedback, the students shared their experiences. In the first lesson, all students had difficulty expressing their own opinion and respecting the other's opinion. They were not used to asking them for their opinion, for the message, of what they had experienced. After the first meeting, the hyperactive children were tired and complained of a headache. The rule was again emphasized - to drink continuously during active music therapy. Already at the third meeting, greater concentration, mastery of even more demanding rhythms, respect for the opinion of the other, responsibility for joint creation, quality verbal feedback for the lesson were recorded.

Within this project, the school management wanted to improve the school climate, support the activity and creativity of children, pupils and teachers, give teachers another tool for earlydiagnostics in the classroom, creating a safe and activating environment and find a way to improve relationships between teachers and pupils. To make children aware of their responsibility for what they do and how they behave, which is a prerequisite for a significant reduction in the aggressive behavior of pupils in school.

\section{As part of the teaching of subjects, teachers recorded in children:}

- Longer attention and focus on assigned tasks

- Greater respect for the teacher's instructions and adherence to the rules

- Willingness to communicate with the teacher and classmates, communication calmer without shouting

- Development of verbal expression

- Overall calmer climate in the classroom, higher motivation to work, willingness to work in a group

- Visible calming in hyperactive pupils and with behavioral disorders, induction of a pupil x pedagogue relationship

- Joy of work done, children's interest in praise, awards, feedback.

Afterwards, teachers in this primary school have the necessary material equipment, their own experience and basic instructions of how they can work with children, how to use elements of music therapy in other subjects. As part of art lessons, they made percussion instruments from various materials, painted them, then decorated them and used them to rhythm in music lessons. 


\section{Figure 2 Music therapy in the primary school}

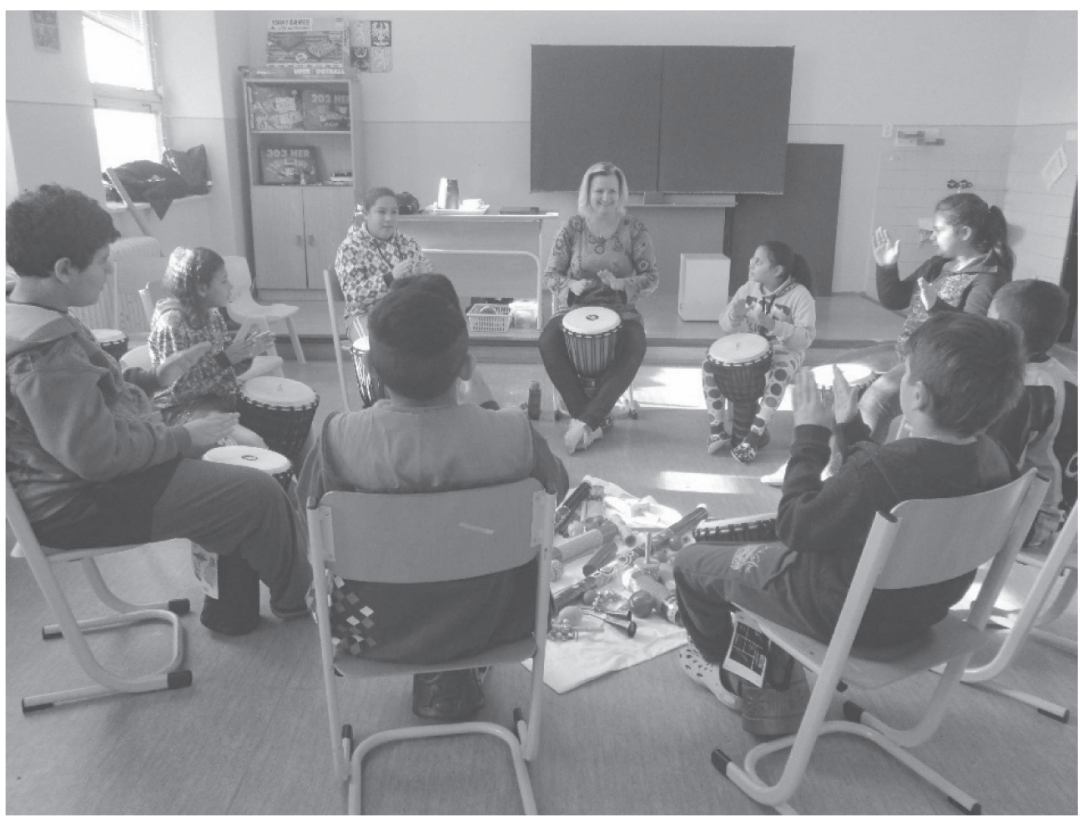

\section{References}

GWYNETH, D. S. (2005). Neverbální komunikace dětí: Jak porozumět dítěti z jeho gest a mimiky. Praha: Portál. ISNB 80-7367-043-7

HALPERN, S., LINGERMAN, H. (2005). Muzikoterapie Léčivá síla hudby. Bratislava: Ekokonzult. ISBN 80-8079-044-2

HOLZER, L., DRLÍČKOVÁ, S. (2012). Celostní muzikoterapie v institucionální výchově. Olomouc: Univerzita Palackého v Olomouci. ISNB 978-80-244-3323-3

KANTOR, J. (2005). Muzikoterapie. In MÜLLER, O. Terapie ve speciální pedagogice. 1 (s. 169-195). Olomouc: UK Olomouc. ISBN 80-244-1075-3.

KANTOR, J., LIPSKÝ, M., WEBER, J. et al. (2009). Základy muzikoterapie. Praha: Grada, 2009. ISBN 978-80-247-2846-9

MAREK, V. (2003). Tajné dějiny hudby. Praha: Eminent. ISBN 80-7281-125-8 
MAREK, V. (2003). Hudba jinak: Hudební nástroje a styly, které mohou zlepšit vaše zdraví a změnit váš život. Praha: Eminent. ISNB 80-7281-125-8

MÜLLER, O. (2005). Terapie ve speciální pedagogice. 1. vydání. Olomouc: UP Olomouc, 295 s. ISBN 80-244-1075-3.

PIPEKOVÁ, J., VÍTKOVÁ, M. (ed.) (2001). Terapie ve speciálně pedagogické péči. 1. vyd. Brno: Paido. ISBN 80-7315-010-7.

VALENTA, M., MÜLLER, O. (2004). Psychopedie: [teoretické základy a metodika]. Vyd. 2. Praha: Parta, s. 443. ISBN 80-732-0063-5.

VÍTKOVÁ, M. (2001). Model „vnímání-představy-myšlení" jako základ terapií ve speciálně pedagogické péči. In Terapie ve speciálně pedagogické péči. 2. vyd. Brno: Paido, Brno, s. 11-17. ISBN 80-7315-010-7.

\section{Author}

PaedDr., Mgr. Irena Johanka Savková, MBA

Special pedagogue, music therapist

Mateřská škola a základní škola speciální Diakonie ČCE Ostrava

U Cementárny 23, 70300 Ostrava-Vítkovice

i.savkova@specialniskola.eu 